\title{
Comparison of Domestic and Foreign Audiologist Education Status and Qualification System
}

\author{
In-Ki Jin ${ }^{1,2}$, Soo Hee Oh ${ }^{3,4}$ \\ ${ }^{1}$ Division of Speech Pathology and Audiology, College of Natural Sciences, Hallym University, Chuncheon, Korea \\ ${ }^{2}$ Research Institute of Audiology and Speech Pathology, College of Natural Sciences, Hallym University, Chuncheon, Korea \\ ${ }^{3}$ Department of Audiology and Speech Language Pathology, Hallym Univesity of Graduate Studies, Seoul, Korea \\ ${ }^{4}$ Center for Hearing and Speech Research, Hallym University of Graduate Studies, Seoul, Korea
}

\author{
Received: May 19, 2021 \\ Revised: June 1, 2021 \\ Accepted: June 2, 2021 \\ Correspondence: \\ Soo Hee Oh, PhD \\ Department of Audiology and \\ Speech-Langauge Pathology, \\ Center for Hearing and Speech \\ Research, Hallym University of \\ Graduate Studies, 427 Yeoksam-ro, \\ Gangnam-gu, Seoul 06197, Korea \\ Tel: $+82-70-8680-6933$ \\ Fax: $+82-2-3453-6618$ \\ E-mail:osh503@naver.com
}

\begin{abstract}
Audiologists are experts in providing specialized treatment for evaluating and managing hearing loss through hearing technology. The purpose of this study is to review the education status of major foreign countries regarding the training of audiologists, their certification management systems, and the audiology education regulations according to international standards; this study compares these with the domestic (i.e., Republic of Korea) education status, certification management system, and audiology education regulations. The regulations, reports, and official documents related to domestic and overseas regarding audiology systems were reviewed and compared. The domestic audiologist education and qualification system is in fair conformity with foreign countries and international standards, but there are areas that need to be improved. If the domestic audiologist qualification system is improved to comply with advanced foreign national audiologist qualification systems and international standards, it will be possible to cultivate a more professional domestic audiologist workforce.
\end{abstract}

Key Words: Audiologist, Standards of hearing aid fitting management, National competency standard, Developmental rehabilitation service.

\section{INTRODUCTION}

난청(hard of hearing)은 유전적 요인, 노화, 소음 노출, 외 상, 감염, 흡연 등의 다양한 원인에 의하여 발생할 수 있으며, 전 세계적으로 난청 인구는 꾸준히 증가하고 있는 추세이다(World Health Organization, 2021). 세계보건기구(World Health Organization, $\mathrm{WHO}$ )는 전 세계적으로 15억 명을 난청인으로 추정하며, 이 중 약 4 억 3 천만 명이 삶의 질 저하를 초래할 수 있 는 중도(moderate) 이상의 난청을 가지고 있다고 보고하였다 (World Health Organization, 2021). 국내의 경우에도 난청 인구는 꾸준히 증가하고 있다. 등록 청각장애인 수의 경우, 2017년 도에는 약 30만 명이었지만 2018년도에는 34만 명으로 증가하 였고, 2019년도에는 37만 명 이상으로 집계하여 매년 청각장 애인 수가 꾸준히 증가하고 있다(Korean Disabled People's

(c) This is an Open Access article distributed under the terms of the Creative Commons Attribution Non-Commercial License (https://creativecommons.org/ licenses/by-nc/4.0) which permits unrestricted non-commercial use, distribution, and reproduction in any medium, provided the original work is properly cited.
Development Institute, 2020). 이는 전체 장애유형별 분류 중 지체장애에 이어 두 번째(14.4\%)로 많은 등록장애 유형이다 (Korean Disabled People's Development Institute, 2020). $\mathrm{WHO}$ 는 국가별 인구의 $10 \%$ 이상이 경도(mild) 이상의 난청을 경험한다고 추산하고 있어 이 추산식을 국내에 적용하면 약 500만 명 이상이 경도 이상의 난청이 있다고 추산할 수 있다(World Health Organization, 2021).

$\mathrm{WHO}$ 는 난청의 효과적인 치료 및 재활을 위한 핵심 전문가 인력(ear and hearing care workforce)으로 소아과, 이비인후 과 및 산부인과 의사, 언어치료사와 더불어 청능사(audiologist) 를 언급하고 있다(World Health Organization, 2021). 미국 청각학회(American Academy of Audiology)는 청능사를 '유 아부터 청소년 및 노인에 이르는 모든 연령대 대상자의 청력손실 및 평형 장애의 평가, 진단, 치료 및 관리를 담당하는 1 차 전문가 ("Audiologists are the primary health-care professionals who evaluate, diagnose, treat, and manage hearing loss and balance disorders in individuals of all ages from 
infants to teens to the elderly.")'로 정의하고 있다(American Academy of Audiology, 2021a). WHO 또한 청능사는 '청 력손실을 진단하고 다루는 데 있어 청각기술에 의한 전문적 케 어(관리)를 제공("Audiologists provide specialist care in diagnosing and addressing hearing loss through hearing technology.")하는 전문가'로 기술하고 있다(World Health Organization, 2021). 이는 국제적 관점에서 청능사가 청력손 실 또는 평형 문제와 관련된 평가, 재활 및 관리를 수행하는 전문 가로 인정된 것이라 할 수 있다.

우리나라보다 일찍이 청능사 제도를 도입한 선진국들은 국가 의 관리하에 청능사의 인력관리 및 질적 제고를 제도화하여 운 영 중에 있다. 미국의 경우에는 청능사를 학부 수준이 아닌 대학 원(doctor of audiology, $\mathrm{AuD}$ ) 수준에서 양성하고 주 법령에 의거하여 관리하고 있다(American Academy of Audiology, 2021b). 또 다른 청각학 선진국인 독일의 경우에도 국가자격시 스템으로 청능사를 관리 및 배출하고 있으며 보건복지법에 보 청기평가 및 조절(fitting) 등의 업무를 청능사의 전문 영역으 로 지정하여 관리 및 운영하고 있다(European Commission, 2021). 그 외 캐나다, 호주, 프랑스 및 인도 등의 국가들도 청능 사를 국가자격시스템으로 운영하거나 최소 교육 수준을 석사 이 상으로 운영하여(Choi, 2017) 청능사의 질적 제고를 통한 수준 높은 청능재활서비스 제공에 노력을 기울이고 있다.

국내의 경우에도 청능사 양성을 위한 대학 교육, 전문자격, 운 영시스템 및 제도적인 부분에서 많은 발전을 이뤄왔다. 현재까 지 청각학 교육은 가야대학교, 남부대학교, 동명대학교, 대구가 톨릭대학교, 부산가톨릭대학교, 세한대학교, 우송대학교, 한림 대학교에서 4년제 학부과정을 통하여 청능사를 배출하였으며, 대학원은 한림국제대학원대학교를 포함하여 국내 6개 대학에 서 석사 또는 박사과정을 운영 중에 있다. 시험자격을 갖춘 학부 나 대학원 재학생 또는 졸업생은 자격기본법에 근거한 민간자격 증인 청능사 시험에 합격한 뒤 자격증을 받을 수 있으며 자격 관 리는 현재 (주)청능사자격검정원(Audiological Testing Service, ATS)에서 주관하고 있다. 이외에도 청능사 및 국내 청각학 전공 자와 관련된 단체로 청각학의 학술적인 제고를 위한 사단법인 한국청각언어재활학회, 청능사의 보수 교육, 권리보호 및 윤리 준수를 위한 한국청능사협회, 청각학 교육의 질적 제고를 위한 한국청각학교수협의회가 있다. 제도적으로는 산업현장에서 직 무를 수행하기 위해 요구되는 지식, 기술, 태도 등의 내용을 국가 가 체계화한 국가직무능력표준에 청각관리영역이 개발(Human Resources Development Service of Korea, 2017)되어 청 각학과가 개설된 대학들의 교육 영역 및 청능사 시험의 범위 기 준으로 활용하고 있다. 또한 장애아동재활서비스의 질적 제고를 위한 전문인력 운영 기반의 바우처사업인 ‘발달재활서비스(보건
복지부고시 제167호, 2018)'가 시행(Ministry of Health and Welfare, 2018)되고 있으며 발달재활영역 중 청능재활을 담당 하는 전문인력 기준을 '청각학 교육을 학부 이상 수료한 대상자 또는 청능사 자격소지자 중 발달재활서비스 관련 추가 교육을 이수한 대상자'로 정하여 운영 중에 있다.

국내 청능사 현황의 경우, 교육, 운영 및 제도 분야에서 지속적 인 발전과 전문적 역량 향상을 추구해 왔다. 2008년 청능사 민 간자격 등록(2008-0354호) 이후 약 2,573명(Yun et al., 2019) 의 합격자를 배출하였고 매년 지속적인 자격시험의 시행과 보수 교육을 통해 청각관리 영역의 전문가를 양성하고 있다. 한편, 청 각관리에 대한 국내외적 수요 증가 및 전문가 역할의 중요성 확 대와 함께 청능사 교육과 자격관리의 향상을 위해 해결해야 할 과제들도 존재한다. 한국보건사회연구원의 '청능사제도 타당성 연구(Yun et al., 2019)' 보고서에 따르면, 국내 난청자의 급증으 로 인한 수요 증가와 해외 선진국들의 청능사 제도에 근거하였을 때, 청능사의 국가자격화가 효과적인 인력관리 및 서비스제공을 위해서 고려될 수 있지만 대학 간 교육 프로그램의 편차가 크며, 전반적으로 국가직무능력표준에 부합하지 못하고 있어 교육의 질적 향상이 동반되어야 한다고 언급하였다. 또한 청능사가 현재 민간자격으로 유지되는 과정에서 기준 미달의 유사 자격증이 난 립하고 있어 소비자들의 혼란을 초래하는 등의 문제가 발생하고 있다고 보고하였다(Yun et al., 2019). 최근 소비자만족도조사 (2013 2017년)에서 의료기기 중 소비자 불만족도가 가장 높은 품목이 보청기로 조사되었고 사후 서비스에 대한 불만이 주요 원 인 중 하나로 나타났다(Bae \& Whang, 2018). 현재 보청기는 자격 제한 없이 판매를 신고한 자는 누구나 판매할 수 있기 때문 에 보청기 사용과 관련된 소비자 불만족은 자격 요건을 갖추고 판매에서 사후관리에 이르는 전반적 서비스를 제공하는 전문가 의 부족에서 그 원인을 찾아볼 수 있을 것이다. 청능사는 보청기 에 관한 이론과 실습을 전공 교과목으로 운영하는 국내 4년제 대학 또는 대학원의 청각학과를 졸업한 전문 인력이며 국내 청각 서비스 향상을 위해서는 청능사를 포함한 청각관리 전문인력의 양성, 교육, 운영 및 제도적 차원에서의 질적 제고가 필요하다고 볼 수 있다.

본 종설의 목적은 해외 주요 국가들의 청능사 양성을 위한 교 육 현황, 자격증관리 제도 및 국제적 기준에서의 청각분야 관련 교육 규정을 살펴보고 국내의 교육 현황, 자격증관리 제도 및 관 련 제도 내 교육 현황과 비교하여 국내 청능사 및 청각관리 전 문가 제도의 질적 제고를 위한 기초 정보를 제공하는 데 있다. 본 리뷰는 국내 청각학 교육의 질적 제고와 청능사 및 청각관 리 전문가 자격의 효율적인 운영에 관한 유용한 정보를 제공할 것이다. 


\section{국내외 청각학 교육 현황 비교}

Goulios and Patuzzi (2008)는 세계 주요 국가들을 대상으로 청능사 양성 및 교육 현황을 보고하였다. 설문조사에 응답한 60국 가 중 18 개 국가(노르웨이, 포르투갈, 독일, 말레이시아, 이집트, 아르헨티나 등)는 청능사를 학사 수준(bachelor degree)에서 양성하고 있었으며, 15 개 국가(벨기에, 인도, 필리핀, 캐나다, 호 주, 뉴질랜드 등)는 학사 또는 석사(master degree) 수준에서 양성하고 있는 것으로 보고하였다. 또한 요르단과 브라질은 학 사, 석사 및 박사(clinical doctorate degree) 수준에서 양성하 며, 네덜란드와 미국은 석사 및 박사 수준에서 양성하고 있는 것 으로 보고하였다. 그 외의 국가들은 특별과정 및 전문학사 수준 에서 양성하는 것으로 보고하였다. 우리나라의 청능사 교육은 학사, 석사 및 박사학위 과정으로 운영되고 있으며, 청능사 시험 의 자격은 청각학 학사 또는 석사학위 과정을 이수한 자로 규정 하고 있다(Audiological Testing Service, 2020). 전 세계의 각 나라별 청능사 교육 현황을 석사학위 이상에서 양성하는 국가, 학사학위 이상에서 양성하는 국가 및 전문 학사학위 이하에서 양성하는 국가로 구분할 때, 우리나라의 현황은 학사학위 이상 에서 양성하는 국가로 분류할 수 있다.

청능사가 활동하는 국가들 중 대부분은 학사 이상의 교육 수 준에서 청능사를 양성하고 있으며, 해당 국가 중 가장 높은 교 육 수준에서 청능사를 양성하고 있는 국가는 미국이다(Goulios \& Patuzzi, 2008). 미국의 청능사는 90여 개의 양성프로그램 이 운영 중에 있으며, 학부 졸업 후 4년의 대학원 과정(AuD)으 로 운영하고 있다(Council on Academic Accreditation in Audiology and Speech-Language Pathology, 2020). 미 국말언어청각협회(American Speech-Language-Hearing Association)에서 공시한 주 면허 규정(Model Regulations for State Licensure, 2016)에서는 청능사 양성을 위한 교육 내용을 다음과 같이 제시하고 있다(Table 1; Appendix 1). 교육 과정은 크게 4가지로 구분하고 있는데, 기초 지식(basic knowledge) 분야는 청각, 평형 및 관련 시스템의 발생학, 해부 학, 유전학 및 생리학, 청각 및 평형기능과 말인지, 의사소통, 난 청과 언어, 난청에 대한 교육, 직업, 사회 및 심리적 영향, 청각과 관련된 평가, 심리음향학과 청각학 연구의 방법과 이해를 주요 과정으로 기술하고 있다. 예방(prevention) 분야는 청각, 평형, 이명 및 의사소통시스템에서의 예방, 소음 노출에 대한 예방 및 조기 선별검사에 대한 내용이 주요 과정으로 기술하고 있다. 평 가(assessment) 분야는 청각평가, 이명 및 평형기능평가, 의사 소통 및 말인지 평가 그리고 청각재활을 위한 평가 및 보정이 주 요 교육 과정으로 기술하고 있다. 중재(intervention) 분야는 청 각재활, 이명재활, 평형재활과 재활 시 활용 가능한 청각보조기 기(보청기 등)에 대한 내용이 주요 과정으로 기술하고 있다. 그
외에 가족 교육 및 상담에 관한 내용을 주요 교육 과정으로 제시 하고 있다. 요약하면, 청각시스템 및 의사소통과 관련된 기초지 식과, 청각기능손실의 예방, 평가 그리고 중재와 관련된 내용이 교육 과정의 주를 이루고 있음을 확인할 수 있다.

유럽청각학회연맹(European Federation of Audiology Societies, EFAS)도 '일반 청능사(general audiologist)' 란 명칭으로 청능사 양성 교육 지침을 발표하였다(European Federation of Audiology Societies, 2001). 해당 교육 지침은 4년 학부 교육 과정(3년 교육 +1 년 임상실습)으로 구성하도록 권고하고 있으며, 유럽 국가들의 청능사 양성을 위한 기본 지침 으로 활용하고 있다. 주요 교육 내용은 미국의 교육 과정 및 내용 과 매우 유사하다(Table 1; Appendix 1). 기초교과목에는 해부 학, 병리학, 언어학 및 청각을 포함하는 의사소통 관련 교과목들 을 포함하고 있으며, 수학, 화학 및 물리학과 같은 기초교과목들 을 포함하고 있다. 미국의 경우에는 학부과정에서 수학, 화학 및 물리학과 같은 기초교과목을 일반적으로 이수하고 $\mathrm{AuD}$ 과정에 입학하기 때문에 미국과 유럽의 기초교과목의 구성은 유사하다 고 볼 수 있다. 유럽 청능사의 교육 지침 중 예방 분야는 소음, 이 독성 약물, 중이염 및 선별검사를 주요 내용으로 제시하고 있으 며, 평가 분야는 청각평가, 중추청각장애평가, 평형기능평가, 음 향측정 및 전기음향학적 평가를 주요 교육 과정으로 제시하고 있다. 중재 분야는 상담, 청각기기의 관리, 재활 및 의사소통 교 육을 주요 교육 과정으로 제시하고 있다. 미국 및 유럽과 같은 국 가들의 청능사 양성을 위한 교육 내용은 매우 유사하다고 볼 수 있으며, 청능사가 되기 위한 역량으로 청각 분야의 예방, 평가, 재 활 및 교육과 상담에 해당하는 폭넓은 지식을 교육하고 있음을 확인할 수 있다. 또한 국제청각학회(International Society of Audiology)도 EFAS 청능사 교육 모델을 2004년에 채택하여 권 고 교육 모델로 제안하고 있다(Goulios \& Patuzzi, 2008).

국내 교육 현황의 경우, (주청능사자격검정원의 청능사 시험 응 시를 위한 최소 교육 과정을 기준으로 교과목을 분류하면, 기초 (청각해부생리, 심리음향, 청력보존, 관련법규) 분야, 평가(행동 청능평가, 전기생리청각평가) 분야, 보청기(보청기적합, 이식형청 각기기적합, 청각보조기기, 청각기기 제작 및 수리) 분야, 재활(청 능재활, 이명재활, 전정기능재활, 중추청각기능재활, 아동청각 학, 노인청각학) 및 실습(평가실습, 보청기실습, 재활실습) 분야로 제시하고 있다(Audiological Testing Service, 2020) (Table 1; Appendix 1). 미국 및 유럽의 권고기준과는 세부 명칭에서 차 이가 있지만, 기초(심리음향학 등) 분야, 예방(청력보존) 분야, 평 가(행동청능평가, 전기생리평가 등) 분야 및 재활(보청기적합, 청 능재활 등) 분야의 교육 과정들로 구성되어 있는 점으로 보아, 국 내의 청능사 교육 내용은 미국, 유럽 및 국제 교육 권고기준에 부 합하는 내용으로 구성되어 있다고 볼 수 있다. 


\section{국제적 기준에서의 청각 분야 관련 규정: 보청기적합관리 표준 내 청각전문가 교육 기준}

보청기는 대다수 난청인의 청능재활에 활용되는 청각기기 로 보청기적합관리(hearing aid fitting management)는 청 능사 업무의 핵심 영역 중 하나이다. 인구 고령화 및 난청인구 의 증가와 함께 보청기 사용자는 증가하고 보청기 산업은 확대 되었으나 보청기적합관리 서비스를 제공하는 청각전문가의 교 육, 보청기적합관리 서비스 수행에 필요한 전제요건 및 수행지 침은 국내외적으로 제각각으로 표준화되어 있지 않아 관련 서
비스 제공과 정책 수립의 기준을 제시하는 데 어려움을 초래하 였다(Oh \& Lee, 2016). 이에 국제표준화기구(International Standard Organization, ISO) 음향기술위원회(Acoustics Technical Committee, TC; TC 43)는 보청기적합관리프로젝 트위원회(Working Group 10, WG 10)를 2016년 5월 11일 신 설하고 보청기적합관리의 표준화 작업을 시작하였다. $\mathrm{ISO}$ 의 보 청기적합관리프로젝트위원회에서는 한국, 미국, 독일, 프랑스, 덴마크, 호주, 일본 등 14 개국 40 명 이상의 전문가가 활동하고 있으며 약 4년간의 작업 끝에 2020년 3월 보청기적합관리 표준

Table 1. The audiology curriculum recommended by USA, EFAS and ISA, and ATS in Korea

\begin{tabular}{|c|c|c|c|}
\hline Area of study & USA & EFAS \& ISA & ATS in Korea \\
\hline Basic knowledge & $\begin{array}{l}\text { - Embryology, anatomy, genetics, and } \\
\text { physiology of hearing systems } \\
\text { - Auditory and vestibular function, } \\
\text { speech perception } \\
\text { - Human communication sciences and } \\
\text { disorders } \\
\text { - Hearing loss on the speech and } \\
\text { language characteristics } \\
\text { - Hearing impairment on educational, } \\
\text { vocational, social, and psychological } \\
\text { function and, consequently, on } \\
\text { full and active participation in life } \\
\text { activities } \\
\text { - Physical characteristics and } \\
\text { measurement of acoustic and non- } \\
\text { acoustic stimuli } \\
\text { - Principles of psychoacoustics and } \\
\text { research }\end{array}$ & $\begin{array}{l}\text { - Mathematics } \\
\text { - Physics } \\
\text { - Communication engineering } \\
\text { - Medicine (e.g., anatomy, embryology, } \\
\text { physiology, pathophysiology) } \\
\text { - Epidemiology } \\
\text { - Chemistry and biochemistry } \\
\text { - Speech and hearing sciences (e.g., } \\
\text { psychoacoustics, linguistics, perception } \\
\text { of speech) } \\
\text { - Developmental psychology and } \\
\text { education } \\
\text { - Research methodology (e.g., } \\
\text { experimental planning, ethics in } \\
\text { research, literature retrieval) } \\
\text { - Medical disciplines (e.g., geriatrics, } \\
\text { pediatrics, genetics) }\end{array}$ & $\begin{array}{l}\text { - Anatomy \& physiology in } \\
\text { audiology } \\
\text { - Psychoacoustics } \\
\text { - Audiology related laws } \\
\text { - Pediatric audiology } \\
\text { - Geriatric audiology }\end{array}$ \\
\hline Prevention & $\begin{array}{l}\text { - Auditory, vestibular, tinnitus, } \\
\text { communication systems } \\
\text { - Noise exposure } \\
\text { - Screening tests }\end{array}$ & $\begin{array}{l}\text { - Noise induced hearing loss } \\
\text { - Ototoxicity } \\
\text { - Otitis media } \\
\text { - Screening tests }\end{array}$ & - Hearing conservation \\
\hline Assessment & $\begin{array}{l}\text { - Audiologic assessment } \\
\text { - Tinnitus \& vestibular system } \\
\text { - Communication \& speech perception } \\
\text { - Tests for rehabilitation } \\
\text { - Calibration }\end{array}$ & $\begin{array}{l}\text { - Audiological assessment (e.g., } \\
\text { otoscopy, psychoacoustic tests, tinnitus } \\
\text { evaluation) } \\
\text { - Tests for central hearing disorders } \\
\text { - Vestibular testing } \\
\text { - Acoustical measurement and calibration } \\
\text { - Electroacoustics }\end{array}$ & $\begin{array}{l}\text { - Auditory behavioral evaluation } \\
\text { - Electro-physiologic auditory } \\
\text { evaluation }\end{array}$ \\
\hline Intervention & $\begin{array}{l}\text { - Aural, tinnitus, vestibular } \\
\text { (re)habilitation } \\
\text { - Assistive device (e.g., hearing aids) } \\
\text { - Family education } \\
\text { - Counseling }\end{array}$ & $\begin{array}{l}\text { - Medical audiology (e.g., pathophysiology } \\
\text { of auditory and vestibular systems, } \\
\text { speech \& language acquisition disorders, } \\
\text { hearing disorders) } \\
\text { - Hearing devices management (e.g., } \\
\text { hearing aids) } \\
\text { - Counseling } \\
\text { - (Re)habilitation } \\
\text { - Education for communication }\end{array}$ & $\begin{array}{l}\text { - Hearing aid fitting } \\
\text { - Implantable hearing device fitting } \\
\text { - Assistive listening device } \\
\text { - Hearing device manufacturing and } \\
\text { repair } \\
\text { - Auditory rehabilitation } \\
\text { - Tinnitus rehabilitation } \\
\text { - Vestibular function rehabilitation } \\
\text { - Central auditory function } \\
\text { rehabilitation }\end{array}$ \\
\hline Reference & $\begin{array}{l}\text { Council on Academic Accreditation } \\
\text { in Audiology and Speech-Language } \\
\text { Pathology, } 2020\end{array}$ & $\begin{array}{l}\text { European Federation of Audiology } \\
\text { Societies, 2001; Goulios \& Patuzzi, } 2008\end{array}$ & Audiological Testing Service, 2020 \\
\hline
\end{tabular}

USA: United States of America, EFAS: European Federation of Audiology Societies, ISA: International society of audiology, ATS in Korea: Korean Audiological Testing Service in Korea 
(International Organization for Standardization, 2020)을 제정하였다.

ISO 21388의 서론에서는 보청기적합관리 표준의 목적은 최 상의 청각재활(the best possible hearing rehabilitation)을 실행하는 것이며, 이는 전문가의 적절한 지식, 훈련 및 기술과 고 객과의 밀접한 상호관계 속에서 체계적인 보청기적합을 제공할 때 달성할 수 있음을 분명히 밝히고 있다. 때문에 보청기적합관 리 표준은 최고의 청각재활서비스 제공을 통한 사용자의 혜택과 만족도 향상을 목표로 하며 이를 위해서 청각전문가의 전문적 역량과 서비스 질 향상을 중심 내용으로 다루고 있다.

먼저 보청기적합관리에 대한 정의(International Organization for Standardization, 2020)를 살펴보면 “보청기적합(hearing aid fitting), 집행(administer), 구조화(organize) 및 제어 (control)의 전 과정에 걸친 체계적 과정(systematic process)" 으로 정의하고 있다. 2018년 제정된 국내 보청기적합관리 표준 (Korean Agency for Technology and Standards, 2018)에 서는 "난청인의 특성에 최적화된 보청기적합을 위한 보청기 선정 과 조절, 사용 및 사후관리에 걸친 전 과정”으로 기술하고 있다. 보청기적합관리 국제 및 국내 표준에서 강조하고 있는 요건 중 하나는 전문가 요건이다. 국제 표준에서는 전문가 교육과 훈련을 위해 이론 1,420 시간, 실습 830 시간, 기타 교육 340시간을 합 하여 총 2,590 시간의 전문가 교육을 권장하고 있으며 연간 최소 10 시간의 기본 보수 교육과 20시간 이상의 권장 보수 교육을 명 시하고 있다. 국내 표준에서는 이론과 실습 교육 540시간, 현장 종합실습 960 시간으로 총 1,500 시간의 보청기전문가 교육을 권 장하고 있고 법적으로 공인된 기관에서 매년 16 시간 이상의 보
수 교육을 받도록 요구하고 있다. 보청기적합관리 국제 및 국내 표준의 전문가 교육 요구사항에 대한 내용을 요약하면 Table 2 (Appendix 2)와 같다.

이처럼 산업표준화법에 의해 제정된 표준 문서에는 보청기전 문가가 보청기적합관리 서비스를 제공하기 위해서 상당시간의 이론과 실무 및 실습 교육을 받아야 하며 매년 지속적인 보수 교 육이 필요함을 명시하고 있다. 이는 전문적인 청각관리 서비스의 핵심이 청각기기의 단순한 제공이 아닌 교육받은 전문가의 지원 과 서비스에 있음을 뒷받침한다. 때문에 청각재활의 성공을 위 해서는 자격을 갖춘 전문가가 필요하고 전문가 양성과 자격 보장 을 위한 제도적 기반과 정책이 마련되어야 할 것이다.

한편, 국제 표준에서는 앞서 설명한 교육 요건 이외에 시설, 장 비, 윤리 요구사항을 포함하고 있다. 시설 요구사항에서는 크게 상담실(consultation area), 청력검사실(audiometric testing room), 적합실(fitting room)을 구분한다. 또한, 적합실의 배경 소음은 $45 \mathrm{dBA}$ sound pressure level 이하로 하고 교정 기간 이 12 개월을 초과하지 않은 청력검사기, 보청기적합 장비, 전기 음향적 측정장비 및 이경검사기를 갖추도록 요구하고 있다. 특히 보청기적합관리 일반 체계는 고객프로파일, 상담, 보청기적합, 확인과 검수, 적합 후 상담, 사후관리의 여섯 개 항목으로 제시하 고 있다. 보청기적합관리 일반 체계의 세부 내용은 평가, 보청기 적합, 확인과 검수, 청능훈련, 상담 등을 포함하고 있다. 이외에 도 문서화, 서비스평가, 고객불만관리 등 서비스 품질관리 측면 에서 전문가가 시행해야 할 사항을 표준 문서에 기술하고 있으며 이러한 전 과정을 수행하고 관리하기 위해서 전문가 교육과 역량 의 중요함을 강조하고 있다.

Table 2. Educational recommendations of ISO 21388 and KS I 0562 for hearing aid professionals

\begin{tabular}{|c|c|c|}
\hline Category & ISO 21388 & KS I 0562 \\
\hline \multirow[t]{2}{*}{ Theory } & $\begin{array}{l}\text { Basic knowledge, biomedicine, human/social science, } \\
\text { audiology, HA technology, hearing rehabilitation } \\
\text { systems, earmould \& custom in the ear devices, selection } \\
\text { \& fitting HA systems \& evaluation of fitting }\end{array}$ & $\begin{array}{l}\text { Basic knowledge, hearing evaluation, hearing devices, } \\
\text { hearing rehabilitation }\end{array}$ \\
\hline & 1,420 hours & 300 hours \\
\hline \multirow[t]{2}{*}{ Practical training } & HA fitting, repair, final project & $\begin{array}{l}\text { Basic knowledge, hearing evaluation, hearing devices, } \\
\text { hearing rehabilitation }\end{array}$ \\
\hline & 830 hours & 240 hours \\
\hline \multirow[t]{2}{*}{$\begin{array}{l}\text { Supplementary } \\
\text { education }\end{array}$} & $\begin{array}{l}\text { Supplementary curriculum: managing a HA professional } \\
\text { practice }\end{array}$ & On-site practice \\
\hline & 340 hours & 960 hours \\
\hline Total hours & 2,590 hours & 1,500 hours \\
\hline $\begin{array}{l}\text { Supplementary } \\
\text { education }\end{array}$ & $\begin{array}{l}\text { Minimum } 10 \text { hours annually (recommendation: } 20 \text { hours } \\
\text { or more) }\end{array}$ & Minimum 16 hours annually \\
\hline Reference & International Organization for Standardization, 2020 & Korean Agency for Technology and Standards, 2018 \\
\hline
\end{tabular}

ISO: International Organization for Standardization, KS: Korean Industrial Standards, HA: hearing aid 
청각관리와 재활의 중요성이 나날이 커지고 있는 현실에서 보 청기적합관리 표준의 제정은 청각서비스 품질 향상과 난청인의 만족도 향상에 크게 기여할 수 있는 국제적 기준 마련이라는 점 에서 의미가 크다. 그리고 이러한 표준을 준수하고 업무를 수행 할 전문가 역할의 중요성은 아무리 언급해도 지나침이 없을 것이 다. 표준의 내용을 어떻게 현실에 적용하고 서비스 품질과 전문 성 향상에 활용해야 하는 것은 이제 우리에게 마주한 새로운 당 면 과제이다.

\section{국가직무능력표준의 청각관리 직무 수행을 위한 교육 요구사항}

국가직무능력표준(National Competency Standard, NCS) (Human Resources Development Service of Korea, 2017) 은 산업현장에서 직무를 수행하기 위해 요구되는 지식, 기술, 태 도 등의 내용을 국가가 체계화한 것이다. 자격기본법 제 2 조에 서는 NCS를 "산업현장에서 직무를 수행하기 위하여 요구되는 지식, 기술, 소양 등의 내용을 국가가 산업부문별 수준별로 체계 화한 것”으로 정의하고 있다. NCS에서는 청능사의 주요 업무 영 역과 내용을 포함하는 청각관리 직무를 다음과 같이 정의하고 있다.

"청각관리는 청각손실로 인한 의사소통의 어려움과 대인관계, 심리사회적, 교육적 및 직업적 기능에 미치는 부정적인 영향을 최소화하거나 예방하기 위하여 행동청능평가, 전기생리청각평 가, 보청기적합관리, 청각이식기적합관리, 청능훈련, 중추청각기 능, 전정기능, 이명재활, 청력보존, 청각관리지원서비스, 청각기 기생산 및 청각산업경영을 수행하는 일이다."

이는 직업인이 현장에서 업무를 수행할 수 있는 능력, 직업인
으로서 기본적으로 갖추어야 할 공통능력, 해당 직무를 수행하 기 위해 필요한 역량(지식, 기술, 태도)을 습득하고 일, 교육, 훈 련, 자격의 연계를 통한 능력중심의 사회를 구현하는 데 목적을 둔다. NCS는 직무의 능력단위, 능력단위 요소 및 능력단위의 수 행 준거(지식, 기술, 태도)로 구성되어 있고 각 직무의 능력단위 별 요소와 전문가가 갖추어야 할 지식, 기술, 태도를 구분하여 기 술하고 있다.

$\mathrm{NCS}$ 에 나타난 청각관리는 청능사 교육 내용의 핵심이며, NCS 청각관리 내용과 요구사항을 확인하는 것은 청능사 교육 을 이해하는 데 도움이 될 수 있다. 청각관리는 총 13 개 능력 단위와 능력단위 요소 및 수준을 체계화하여 제시하고 있다. 특 히 능력단위의 수준은 1 에서 8 수준으로 구분되며 수준이 커질 수록 요구되는 기술, 역량, 경험 및 학위 수준이 높다. Table 3 에서는 청각관리 영역의 13 개 능력단위와 능력단위수준 및 학 위 수준을 보여주며 능력단위요소가 포함된 추가적인 내용은 Appendix 3에서 확인할 수 있다. 학위 예시에서 보여주는 것처 럼 청각관리 영역의 전문가는 교육 수준이 대졸 학사 이상인 능 력수준 4 부터 시작한다. 이를 사무관리직에 적용하였을 때는 대 리 이상, 국가기술자격 예시에서는 기사 자격 이상의 수준을 요 구하고 있어 NCS에서도 청각관리 영역의 전문가는 높은 수준의 교육과 훈련 및 기술이 필요함을 명시하고 있다.

\section{청능사와 발달재활서비스의 청능재활서비스 제공 인력}

청능재활은 청능사 직무와 관련하여 최근 강조되는 발달재활 서비스 영역이다. 발달재활서비스는 장애아동복지지원법에 근 거하여 만 18 세 미만 발달장애아동을 대상으로 국가에서 지원

Table 3. Competencies and educational requirements of hearing management in NCS

\begin{tabular}{lcc}
\hline Competency unit & Competency level & Education degree \\
\hline Behavioral hearing evaluation & 5 & Master \\
Electrophysiology hearing evaluation & 4 & Bachelor \\
Hearing aid fitting management & 6 & Master \\
Implantable hearing device fitting management & 6 & Master \\
Auditory training & 6 & Master \\
Central auditory processing rehabilitation & 6 & Master \\
Vestibular rehabilitation & 6 & Master \\
Tinnitus rehabilitation & 6 & Master \\
Hearing conservation & 7 & Audiology doctor/Ph.D. \\
Hearing management research & 8 & Audiology doctor/Ph.D. \\
Hearing management service & 7 & Audiology doctor/Ph.D. \\
Hearing device production & 4 & Bachelor \\
\hline Hearing industry management & 8 & Audiology doctor/Ph.D. \\
\hline
\end{tabular}

NCS: National Competency Standard 
하는 서비스이다. 발달재활서비스 적용 영역은 언어재활, 청능재 활, 미술심리재활, 음악재활, 놀이심리재활, 행동재활, 재활심리, 감각발달재활, 운동발달재활, 심리운동 및 발달재활서비스 자격 관리위원회의 심의를 거쳐 정하는 기타 영역을 포함한다. 또한 2018년 9월 12일 시행한 〈발달재활서비스 제공 인력의 자격 및 인정 절차 기준에 관한 고시>(보건복지부고시 제 167호)에 근거 하여 자격을 갖춘 자에 한해 발달재활서비스를 제공하도록 하고 있다. 발달재활서비스 제공 인력 자격인정 영역은 감각발달재활, 놀이심리재활, 미술심리재활, 심리운동, 운동발달재활, 재활심 리, 청능재활, 행동재활, 음악재활 9개 영역으로 각 영역별 자격 인정을 신청할 수 있다(장애아동복지지원법 시행규칙 제8조 1항, 보건복지부 고시 2020-335호 발달재활서비스 제공 인력의 자 격 및 인정절차 기준).

발달재활서비스 제공 인력 자격인정에서 청능재활 영역은 청 능사 또는 대학의 청각학 전공자 중 서비스 제공에 필요한 과목 을 이수한 사람이 발달재활서비스를 제공할 수 있는데 자세한 관련 내용은 Appendix 4와 같다. 또한, 발달재활서비스 자격 인증 절차는 처음 고시가 시행된 2018년 9월 12일을 기준으로 다르게 진행되는데 Appendix 5는 각각 대상자의 자격 인증 절 차를 보여준다. 이를 요약하자면 대학/대학원의 청각학 전공자 중 2018년 9월 12일 이전 청능사 자격증 소지자는 전환 교육을 이수한 뒤 신청하고 2018년 9월 12일 이후 청각학 전공자는 필 요 교과목을 이수한 뒤 신청하여 발달재활서비스 제공 인력 자 격 심사를 거쳐 청능재활서비스 제공 인력이 될 수 있다.

발달재활서비스는 성장기 장애아동의 인지, 의사소통, 적응행 동, 감각 및 운동 등의 정신적, 감각적 기능 향상과 행동발달을 위한 적절한 발달재활서비스의 지원 및 정보 제공을 목적으로 하며 높은 발달재활서비스 비용으로 인한 장애아동 양육가족의 경제적 부담을 경감하기 위한 목적으로 시작한 사업이다. 서비스 대상자는 만 18 세 미만의 장애아동으로 장애유형은 시각, 청각, 언어, 지적, 자폐성, 뇌병변 장애아동을 포함한다. 서비스의 내 용은 언어, 청능, 미술심리재활, 음악재활, 행동, 놀이심리, 재활 심리, 감각발달재활, 운동발달재활, 심리운동 등 발달재활서비 스를 제공하고 의료행위인 물리치료와 작업치료 등 의료기관에 서 행해지는 의료지원은 포함하지 않는다(Ministry of Health and Welfare, 2021).

이처럼 발달재활서비스의 청능 분야는 청능사 및 대학에서 청 각학을 전공한 사람이 제공하는 영역으로 청능사의 전문성과 교육 및 자격의 필요성을 뒷받침하는 중요한 근거가 된다. 또한 청각장애인의 청능발달을 향상시키고 장애인 복지에 기여할 수 있는 청능재활 전문가 확대와 인력 양성이 사회 및 제도적으로 필요함을 보여준다.

\section{국내외 청능사 자격제도 비교}

해외에서 청능사는 국가에 따라 주로 국가법령제도 또는 전 문민간단체(협회 등)에 의해서 자격관리가 이루어지고 있다. 이 중 대표적으로 청각학을 주도하는 미국, 독일, 호주, 캐나다, 영 국과 대한민국의 청능사 자격제도를 Table 4 (Appendix 6)에 기술하였다(Audiological Testing Service, 2020; Audiology Australia, 2018; Council on Academic Accreditation in Audiology and Speech-Language Pathology, 2020; European Commission, 2021; Goulios \& Patuzzi, 2008; Model Regulations for State Licensure, 2016; SpeechLanguage \& Audiology Canada, 2021; Yong et al., 2019). 미국의 경우, 청능사 $(\mathrm{AuD})$ 가 되기 위한 최소 교육 수준을 4년 의 대학원 과정으로 규정하고 있으며, 청능사 시험 응시 전 12개 월의 임상경험을 필수로 요구하고 있다. 미국은 90 여 개의 대 학에서 청능사 프로그램을 운영하고 있으며, 주 법령에 의거 하여 청능사 자격제도를 운용 중에 있다. 독일의 경우, 청능사 (acoustician)가 되기 위한 최소 교육 수준은 3년 또는 4년의 학 사 과정으로 규정하고 있으며, 청능사 시험 응시 전 임상경험은 따로 요구하지 않는다. 독일은 4 개의 대학에서 청능사 교육 프 로그램을 운영하고 있으며, 국가법령에 의거하여 청능사 자격제 도를 운용하고 있다. 호주의 경우, 청능사가 되기 위한 최소 교육 수준은 2 년 이상의 석사 과정을 포함한 5 년의 대학 학위과정으 로 규정하고 있으며, 청능사가 되기 위해서는 12 개월의 임상경험 을 필수로 요구하고 있다. 호주는 6 개의 대학에서 청능사 교육 프 로그램을 운영하고 있으며, 전문가 기반의 민간기관('Audiology Australia')에서 청능사 자격제도를 관리 및 운용하고 있다. 캐 나다의 경우, 청능사가 되기 위한 최소 교육 수준은 2 년 또는 3 년의 석사 과정으로 규정하고 있으며, 청능사가 되기 위해서는 350 시간의 임상경험을 필수로 요구하고 있다. 캐나다는 5 개의 대학에서 청능사 교육 프로그램을 운영하고 있으며, 전문가 기 반의 민간기관('Speech-Language \& Audiology Canada')에 서 청능사 자격제도를 관리 및 운용하고 있다. 영국의 경우, 청 능사가 되기 위한 최소 교육 수준은 2 년 또는 3 년의 학사 또는 석사 과정으로 규정하고 있으며, 청능사 시험 응시 전 임상경험 은 따로 요구하지 않는다. 영국은 12 개의 대학에서 청능사 교육 프로그램을 운영하고 있으며, 전문가 기반의 민간기관('British Society of Audiology')에서 자격제도를 관리 및 운용하고 있 다. 우리나라의 경우, 청능사가 되기 위한 최소 교육 수준은 4년 의 학사 과정 또는 2 년의 석사 과정으로 규정하고 있으며, 청능 사 시험 응시 전 임상경험을 따로 요구하진 않는다. 또한 9개의 대학에서 프로그램을 운영 중에 있으며, 전문가 기반 민간기관 ('Audiological Testing Service')에서 자격제도를 관리 및 운 용하고 있다. 
Table 4. Certification system for audiologist of United States, Germany, Australia, Canada, United Kingdom, and South Korean in audiology

\begin{tabular}{|c|c|c|c|c|c|c|}
\hline & United States & Germany & Australia & Canada & United Kingdom & South Korea \\
\hline $\begin{array}{l}\text { Minimum education } \\
\text { level }\end{array}$ & $\begin{array}{l}\text { Graduate (4-year: } \\
\text { doctorate degree) }\end{array}$ & $\begin{array}{l}\text { Under-graduate } \\
\text { (3-4 years) }\end{array}$ & $\begin{array}{l}\text { Graduate (5- } \\
\text { year: bachelor's } \\
\text { + master's } \\
\text { degree) }\end{array}$ & $\begin{array}{l}\text { Graduate (2-3 } \\
\text { years: master's } \\
\text { degree) }\end{array}$ & $\begin{array}{l}\text { Graduate \& } \\
\text { under-graduate } \\
\text { (2-3 years: } \\
\text { bachelor's or } \\
\text { master's degree) }\end{array}$ & $\begin{array}{l}\text { Graduate ( } 2 \text { year } \\
\text { master's degree) } \\
\text { or under- } \\
\text { graduate ( } 4 \text { year } \\
\text { bachelor's degree) }\end{array}$ \\
\hline $\begin{array}{l}\text { Minimum clinical } \\
\text { supervision }\end{array}$ & 12 months (full-time) & None & $\begin{array}{l}12 \text { months (full- } \\
\text { time) }\end{array}$ & 350 hours & None & None \\
\hline Number of programs & 90 & 4 & 6 & 5 & 12 & 9 \\
\hline $\begin{array}{l}\text { Certification } \\
\text { (or license) } \\
\text { management } \\
\text { authority }\end{array}$ & State law & $\begin{array}{l}\text { German federal } \\
\text { statutory law }\end{array}$ & $\begin{array}{l}\text { Professional } \\
\text { body } \\
\text { (Audiology } \\
\text { Australia) }\end{array}$ & $\begin{array}{l}\text { Professional } \\
\text { body (Speech- } \\
\text { Language \& } \\
\text { Audiology } \\
\text { Canada) }\end{array}$ & $\begin{array}{c}\text { Professional body } \\
\text { (British Society } \\
\text { of Audiology) }\end{array}$ & $\begin{array}{l}\text { Professional body } \\
\text { (Audiological } \\
\text { Testing Service) }\end{array}$ \\
\hline Reference & $\begin{array}{l}\text { Goulios \& Patuzzi, } \\
\text { 2008; Model } \\
\text { Regulations for State } \\
\text { Licensure, 2016; } \\
\text { Council on Academic } \\
\text { Accreditation in } \\
\text { Audiology and } \\
\text { Speech-Language } \\
\text { Pathology, 2020 }\end{array}$ & $\begin{array}{l}\text { Goulios \& } \\
\text { Patuzzi, } \\
\text { 2008; Yong } \\
\text { et al., 2019; } \\
\text { European } \\
\text { Commission, } \\
2021\end{array}$ & $\begin{array}{l}\text { Audiology } \\
\text { Australia, } 2018\end{array}$ & $\begin{array}{l}\text { Speech- } \\
\text { Language \& } \\
\text { Audiology } \\
\text { Canada, 2021 }\end{array}$ & $\begin{array}{l}\text { Goulios \& } \\
\text { Patuzzi, 2008; } \\
\text { Yong et al., 2019 }\end{array}$ & $\begin{array}{l}\text { Audiological } \\
\text { Testing Service, } \\
2020\end{array}$ \\
\hline
\end{tabular}

국내외 청능사 자격제도를 비교하면, 최소 교육 레벨은 학사 취득 후 4 년의 대학원 과정으로 운영하는 미국이 가장 높으며 다 른 해외 국가들은 학사 또는 석사 과정으로 규정하고 있어 대한 민국과 유사하게 운영하고 있다. 청능사 시험 응시 전 임상경험 (전문가 관리 감독하에 진행)은 미국과 호주는 12 개월로 가장 높은 임상경험 수준을 요구하고 있으며, 그 다음이 350시간을 요구하는 캐나다이다. 대한민국, 독일 및 영국은 청능사가 되기 위한 임상경험을 요구하지 않아 자격 취득을 위한 진입장벽이 미 국, 호주 및 캐나다에 비해 낮은 수준으로 운영됨을 확인할 수 있 다. 청능사 프로그램을 운영하는 대학의 수는 미국이 90여 개로 가장 많으며 대한민국을 포함한 나머지 국가들은 4 개에서 12 개 사이의 대학에서 운영하고 있다. 청능사 자격의 관리는 미국과 독일은 국가 또는 주 법령에 의거하여 면허 수준으로 운영되는 반면, 대한민국, 호주, 캐나다 및 영국은 민간 자격으로 운용하고 있음을 확인할 수 있다. 해외 국가들 중 청능사 자격제도를 가장 체계적으로 운영하고 있는 선진국은 미국이며, 최소 교육 수준 및 임상경험 요구수준, 청능사 프로그램 제공 교육 기관 개수 및 자격제도의 관리주체를 포함한 모든 면에서 국내보다 높은 수준 으로 운영되고 있음을 확인할 수 있다.

\section{DISCUSSIONS}

본 종설은 국내 및 해외 주요 국가들의 청능사 양성을 위한 교
육 제도를 분석하였다. 청능사 자격제도를 운용하고 있는 해외 주요 국가들의 교육 제도와 비교할 때, 국내의 청능사 교육 제도 는 교과내용, 최소 교육 수준, 개설 대학 수 등에서 세계 최고수 준인 미국(최소 교육 수준: 대학원 4년 과정, 개설 대학 수: 90개) 을 제외하고 다른 국가들과 유사한 수준인 것을 확인할 수 있었 다(Table $1 \& 4$ ). 하지만 임상수련요건과 실습 교육시간 측면 에서는 국내 청능사 교육 제도의 보완이 필요해 보인다. 미국과 호주의 경우에는 교과 과정 이수 후에 청능사 자격시험에 응시 하기 위해서 최소 12 개월의 임상수련(감독자 지도하에 실시)을 필수로 요구하고 있다(Audiology Australia, 2018; Council on Academic Accreditation in Audiology and SpeechLanguage Pathology, 2020). 또한 캐나다도 350시간의 임 상수련을 필수 과정으로 운영하고 있다(Speech-Language \& Audiology Canada, 2021). 우리나라의 경우에는 현재 청 능사 자격시험 응시 전 따로 임상수련시간을 요구하지 않고 있 으며 다만 청능사 자격 취득 후 임상경력 6년 이상인 경우 심 의를 거쳐 전문청능사의 자격을 부여하고 있다(Audiological Testing Service, 2020). 숙련된 실무경험이 있는 청능사의 감 독(supervision) 하에 실시하는 임상수련 교육은 이론과 실습 을 통해 교육받은 내용을 현장에서 직접 적용하고 업무의 숙련 도를 향상시킬 수 있다는 장점이 있다.

국내 청능사 교육 개선을 위해 고려해야 할 또 다른 요인은 청 능사 교육 과정 내 실습시간의 확대이다. 현재 청능사 자격시험 
에 응시하기 위한 최소 실습 교육시간은 240시간(Audiological Testing Service, 2020)으로 관련 국가 표준인 국내 보청기적합 관리 표준(Korean Agency for Technology and Standards, 2018)에서 권장하는 실습 교육시간(240시간)과 동일한 수 준이지만 국제적 기준에는 부합하지 못하고 있다. 현재 청능 사 교육에 미국, 유럽 및 세계 주요 국가들의 청각전문위원들 이 참여해 제정한 국제 보청기적합관리 표준(International Organization for Standardization, 2020)에서는 보청기전문 가가 되기 위한 권고 실습 교육시간을 830시간으로 제시하고 있 다. 또한 국내 표준에서도 실습 교육 이외에 960시간의 현장종 합실습을 명시하여 실습 교육과 현장종합실습을 합해 총 1,200시 간의 실습 교육을 권장하고 있다. 실습은 이론의 실무적용능력 을 향상시킬 수 있는 교육 방법이다. 청능사의 실무적용 능력 및 숙련도는 해외 주요 국가들의 교육 시스템 및 국제 제도와 표준 에서도 비중 있게 다루고 있는 만큼, 보다 전문적 수준의 청능사 양성을 위해서는 국내 청능사 교육 제도에 국제적 수준에 부합 하는 실습시간 확보 및 임상수련제도의 도입이 필요해 보인다.

청능사 자격제도의 확립과 관련하여 해외 주요 국가들의 청능사 자격(면허) 관리의 운영형태는 두 가지로 나눌 수 있다(Table 4). 캐 나다 및 영국과 같은 국가들은 전문 학회 등의 민간단체에서 자 격의 관리를 운영하고 있어 (주청능사자격검정원이 관리하는 우 리나라의 운영 방식과 유사하다. 반면, 미국과 독일은 국가 또는 주 법령에 의거하여 국가차원에서 면허 수준의 자격형태로 관리 하고 있다. 이렇듯 각 나라의 정책에 따라 민간 주도 또는 정부 주도의 청능사 자격제도를 운용하고 있으나 한 가지 분명한 사실 은 미국, 호주, 독일, 캐나다 등 대부분 국가에서 관련 민간단체 와 국가가 청능재활서비스 향상을 위해 서로 긴밀하게 협조하고 정책을 수립하며 정부, 민간 또는 정부와 민간의 긴밀한 협조 하 에 청능사의 전문성을 인정하고 자격제도를 운용하고 있다는 사 실이다.

서론에서 언급한 국내 청각장애현황과 청능재활서비스의 수 요 증대 및 질 향상의 필요성 등 여러 가지 여건을 고려하면 효과 적인 인력관리 측면에서 청능사 자격제도는 국가 차원에서 국가 자격화를 통해 관리하는 것이 타당해 보인다. 청능사의 국가자격 화는 대학별 교육 제도의 상향 평준화를 촉진할 수 있다. 한국보 건사회연구원의 '청능사제도 타당성 연구(Yun et al., 2019)' 보 고서에서 대학별 교육 여건의 차이로 인하여 상향 평준화된 청 능사 양성의 필요성을 언급한 바 있다. 민간단체(주)청능사자격검 정원)에서 민간 자격을 위한 각 대학의 교육 여건(인력, 장비 및 시설, 교육 과정 확충 등) 개선 요구를 통해 상향 평준화를 실현 하는 것은 경제적인 부분을 포함하여 현실적으로 추진이 어려울 수 있다. 하지만 국가자격화를 통해 상향 평준화된 교육 여건을 조성할 수 있으며 이를 국가가 관리한다면, 청각학과를 운영하
는 대학들은 교육 여건의 개선을 보다 빠르게 실현할 수 있을 것 이다.

국가 차원의 관리가 가장 이상적으로 보이지만 국가자격시스 템이 구축되기 이전에 민간 차원에서 우선적으로 시행할 수 있 는 대학별 교육 환경의 상향 평준화 방안으로 '교육 인증제' 도입 을 고려할 수 있다. Lee et al.(2017)은 미국과 같이 청능사 제도 를 운영 중인 국가들은 대학별 청각학과의 교육 환경 관리를 위 한 교육 인증시스템을 운영 중이며, 우리나라의 경우에도 교과 목명 및 내용, 전임교원 강의 비율 및 실습환경(실습실 및 기자재 등) 등의 요소를 교육 인증제를 통해 대학별 교육 환경을 향상시 킬 수 있다고 제언하였다. 청각학과를 운영 중인 대학들의 적극 적인 참여와 소통을 통해 국내 환경에 적합한 교육 인증 기준을 정하고 점차 상향해 나간다면 더욱 수준 높은 청능사를 양성할 수 있는 교육 환경이 구축될 것이다. 따라서 청각학 교육을 시행 하는 대학을 대상으로 교육 인증시스템을 관련 학회 또는 협회 차원에서 도입하기를 제언한다.

또한 ‘청능사제도 타당성 연구(Yun et al., 2019)' 보고서에서 는 국내에 이미 관련 유사자격증이 난립하여 소비자들이 혼란을 초래하는 등의 문제가 발생하고 있다고 언급하였다. 만약 청능사 제도가 국가자격화를 통해 관리된다면 소비자들의 혼란이나 피 해 감소에 기여할 수 있을 것이다. 세계보건기구를 포함하여 세 계 주요 국가들은 청능사를 난청을 관리하는 전문인력 중 하나 임을 공식적으로 제시하고 있다(World Health Organization, 2021). 세계보건기구에서 지정한 청능사 외 전문인력에는 소아 과 의사, 이비인후과 의사, 산부인과 의사와 언어치료사가 있는 데 국내에서는 모두 국가 차원의 자격 또는 면허제도를 통해 인 력을 관리하고 있다. 이러한 점들을 감안할 때, 국내 청능사 자격 제도는 국가 자격체계 내에서 관리하는 것이 인력의 질적인 향상 과 타 전문가와의 자격관리 형평성 면에서 타당해 보인다. 궁극 적으로 이러한 제도적 관리는 국내 난청인들의 복지 향상에 기여 할 것이다.

장애인을 위한 복지서비스의 방향이 이용자 중심의 사회적 참 여와 활동의 기능성(World Health Organization, 2001)으로 전환되고 있는 시점에서 청력손실로 인해 생애 전반에 걸쳐 발생 하는 학습, 의사소통, 대인관계, 공동체 생활 등에서의 활동 및 참여를 촉진하고, 기술, 태도, 지원, 정책 등과 관련된 환경요인 을 파악, 지원하는 것은 무엇보다도 중요하다(Oh, 2015). 이를 위해서는 청능재활을 통해 청각장애인의 사회참여를 지원할 수 있는 전문인력의 양성과 자격제도의 확립이 가장 선행되어야 하 며, 청능재활서비스 전문가인 국내 청능사의 양성 및 자격제도에 서의 변화와 개선 및 국가적 지원이 필요하다. 보청기, 인공와우 등 청각기기의 단순한 제공은 청능재활서비스의 질적 향상과 사 용자 만족을 이끌어 낼 수 없으며, 국가자격에 기반한 청능재활 
전문인력의 양성을 통한 생애 주기에 걸친 전문서비스의 제공은 청능재활서비스의 질적 제고 창출과 이용자 만족도 향상에 기여 할 수 있을 것으로 기대한다.

중심 단어 : 청능사, 보청기적합관리 표준, 직무능력표준, 발 달재활서비스.

\section{Ethical Statement}

N/A

\section{Acknowledgments \\ N/A}

\section{Declaration of Conflicting Interests}

There are no conflict of interests.

\section{Funding \\ N/A}

\section{Author Contributions}

Conceptualization: In-Ki Jin, Soo Hee Oh. Data curation: In-Ki Jin. Investigation: In-Ki Jin, Soo Hee Oh. Validation: InKi Jin, Soo Hee Oh. Writing-original draft: In-Ki Jin, Soo Hee Oh. Writing_review \& editing: In-Ki Jin, Soo Hee Oh. Approval of final manuscript: In-Ki Jin, Soo Hee Oh.

\section{ORCID ID}

In-Ki Jin

$$
\text { https://orcid.org/0000-0002-0834-5981 }
$$

Soo Hee Oh https://orcid.org/0000-0002-3745-1484

\section{REFERENCES}

American Academy of Audiology. (2021a, May 20). What is an Audiologist? American Academy of Audiology. Retrieved from https://www.audiology.org/what-is-an-audiologist.

American Academy of Audiology. (2021b, May 20). State audiology licensing laws. American Academy of Audiology. Retrieved from https://www.audiology.org/advocacy/legislative-and-regulatoryactivities/state-affairs/state-audiology-licensing-laws/.

Audiological Testing Service. (2020, January 17). Audiologist management and operation regulations. Audiological Testing Service. Retrieved from http://www.audiologykorea.or.kr/main/ QUALIFICATION.ASP?SUBID $=0 \& I D=2$.

Audiology Australia. (2018, May 12). About audiologist. Audiology Australia. Retrieved from https://audiology.asn.au/Consumer_ Hub/About_Audiologists/Qualifications_and_training.

Bae, S. \& Whang, M. (2018). A study on measures to improve consumer issues of medical device markets for elderly consumers: Focusing on hearing aids and relevant services. Consumer Policy, 94, 1-131.

Choi, C. H. (2017). Chapter 1: Expertise of audiology. In Korean Audiology Professors' Association. (2nd ed.). Introduction to Audiology (pp.13-29). Seoul: HAKJISA.

Council on Academic Accreditation in Audiology and SpeechLanguage Pathology. (2020). Standards for accreditation of graduate education programs in audiology and speech-language pathology. Rockville, MD: American Speech-Language-Hearing Association.

European Commission. (2021, April 12). Hearing aid dispenser / audiometric technician. European Commission. Retrieved from https://ec.europa.eu/growth/tools-databases/regprof/index. cfm?action=regprof\&id_regprof $=927$.

European Federation of Audiology Societies. (2001, April 15). General audiologist. European Federation of Audiology Societies. Retrieved from http://www.efas.ws/noticeboard/general_audiologist.htm.

Goulios, H. \& Patuzzi, R. B. (2008). Audiology education and practice from an international perspective. International Journal of Audiology, 47(10), 647-664.

Human Resources Development Service of Korea. (2017, May 12). National competency standards, hearing management. Human Resources Development Service of Korea. Retrieved from https:// www.ncs.go.kr/unity/th03/selectKeywordSearch.do.

International Organization for Standardization (ISO). (2020). ISO 21388: Acoustics-Hearing Aid Fitting Management. Geneva: ISO.

Korean Disabled People's Development Institute. (2020). 2020 Statistical Yearbook of Disabilities. Seoul: Korean Disabled People's Development Institute.

Korean Agency for Technology and Standards (KATS). (2018). KS I 0562: Acoustics-Hearing Aid Fitting Management. Eumseong, Chungbuk: KATS.

Lee, J. H., Lee, J. Y., Cho, S. J., Park, S. I., Kim, J. D., Park, M. H., et al. (2017). A survey of educational environment for the accreditation of audiology and hearing sciences education. Audiology and Speech Research, 13(3), 193-208.

Ministry of Health and Welfare. (2018, September 12). Ministry of Health and Welfare Notice no.167, standards for qualifications and accreditation procedures for personnel providing developmental rehabilitation service. Ministry of Health and Welfare. Retrieved from https://www.law.go.kr/LSW/admRulLsInfoP.do?admRulSeq= 2100000147649.

Ministry of Health and Welfare. (2021, April 12). 2021 family support program of children with disabilities. Ministry of Health and Welfare. Retrieved from http://www.mohw.go.kr/react/jb/sjb030301vw. jsp?PAR_MENU_ID $=03 \&$ MENU_ID $=032901 \&$ CONT SEQ=364935.

Model Regulations for State Licensure. (2016). Model Regulations for State Licensure of Audiologists, Speech-Language Pathologists, and Audiology and Speech-Language Pathology Assistants. Rockville, MD: American Speech-Language-Hearing Association.

Oh, S. H. (2015). Application of international classification of functioning, disability and health (ICF) core sets in outcome measurements for hearing loss. Audiology, 11(3), 171-185.

Oh, S. H. \& Lee, J. (2016). General framework of hearing aid fitting management. Journal of Audiology and Otology, 20(1), 1-7.

Speech-Language \& Audiology Canada (SAC). (2021, March 20). Becoming an audiologist. SAC. Retrieved from https://www.sacoac.ca/audiology/becoming-audiologist.

World Health Organization. (2001). International Classification of 
Functioning, Disability and Health (ICF). Geneva: World Health Organization.

World Health Organization. (2021). World Report on Hearing. Geneva: World Health Organization.

Yong, M., Willink, A., McMahon, C., McPherson, B., Nieman, C. L., Reed, N. S., et al. (2019). Access to adults' hearing aids: Policies and technologies used in eight countries. Bulletin of the World Health Organization, 97(10), 699-710.

Yun, G., Kim, H., Cohi, S., Kim, I., \& Jung, J. (2019). A Study on the Feasibility of the Audiology System (pp.1-170). Sejong: Korea Institute for Health and Social Affairs. 


\section{APPENDIX}

Appendix 1. 미국, 유럽청각학회연맹 및 국제청각학회, 한국 (주)청능사자격검정원의 청능사 권고 교육 과정

\begin{tabular}{|c|c|c|c|}
\hline 학문영역 & 미국 & 유럽청각학회연맹 \& 국제청각학회 & 한국 (주)청능사자격검정원 \\
\hline 기초 지식 & $\begin{array}{l}\text { - 청각시스템 관련 발생학, 해부학, } \\
\text { 유전학 및 생리학 } \\
\text { - 청각 및 전정 기능, 어음 인지 } \\
\text { - 의사소통 과학 및 장애 } \\
\text { - 말 및 언어와 청력손실 } \\
\text { - 교육, 직업, 사회 및 심리적 기능에 대한 } \\
\text { 청각장애 및 삶의 질 향상 } \\
\text { - 음향 및 비음향 자극에 대한 물리적 } \\
\text { 특성 및 측정 } \\
\text { - 심리 음향학 및 연구 원리 }\end{array}$ & $\begin{array}{l}\text { - 수학, 물리학, 통신 공학 } \\
\text { - 의학(예: 해부학, 발생학, 생리학, 병태 } \\
\text { 생리학) } \\
\text { - 역학 } \\
\text { - 화학 및 생화학 } \\
\text { - 언어 및 청각 과학(예: 심리음향학, } \\
\text { 언어학, 어음 인지) } \\
\text { - 발달 심리학 및 교육 } \\
\text { - 연구 방법론(예: 실험 계획, 연구 윤리, } \\
\text { 문헌 검색) } \\
\text { - 의료 분야(예: 노인학, 소아과, 유전학) }\end{array}$ & $\begin{array}{l}\text { - 청각해부생리 } \\
\text { - 심리음향 } \\
\text { - 관련법규 } \\
\text { - 아동청각학 } \\
\text { - 노인청각학 }\end{array}$ \\
\hline 예방 & $\begin{array}{l}\text { - 청각, 전정, 이명 및 의사소통시스템 } \\
\text { - 소음 노출 } \\
\text { - 선별검사 }\end{array}$ & $\begin{array}{l}\text { - 소음으로 인한 청력손실 } \\
\text { - 이독성 약물 } \\
\text { - 중이염 } \\
\text { - 선별검사 }\end{array}$ & - 청력보존 \\
\hline 평가 & $\begin{array}{l}\text { - 청력평가 } \\
\text { - 이명 및 전정시스템평가 } \\
\text { - 의사소통 및 어음 인지평가 } \\
\text { - 재활관련 평가 } \\
\text { - 보정 }\end{array}$ & $\begin{array}{l}\text { - 청력평가(예: 이경검사, 심리음향검사, } \\
\text { 이명평가) } \\
\text { - 중추청각장애평가 } \\
\text { - 전정평가 } \\
\text { - 음향평가 및 보정 } \\
\text { - 전기음향평가 }\end{array}$ & $\begin{array}{l}\text { - 행동청능평가 } \\
\text { - 전기생리청각평가 }\end{array}$ \\
\hline 중재 & $\begin{array}{l}\text { - 청각, 이명, 전정재활 } \\
\text { - 보조기기(예: 보청기) } \\
\text { - 가족 교육 } \\
\text { - 상담 }\end{array}$ & $\begin{array}{l}\text { - 의료청각학(예: 청각 및 전정시스템의 } \\
\text { 병태생리학, 언어 및 언어습득장애, 청각 } \\
\text { 장애) } \\
\text { - 보청기 관리(예: 보청기) } \\
\text { - 상담 } \\
\text { - 재활 } \\
\text { - 의사소통 교육 }\end{array}$ & $\begin{array}{l}\text { - 보청기 적합 } \\
\text { - 이식형청각기기 적합 } \\
\text { - 청각보조기기 } \\
\text { - 청각기기 제작 및 수리 } \\
\text { - 청능재활 } \\
\text { - 이명재활 } \\
\text { - 전정기능재활 } \\
\text { - 중추청각기능재활 }\end{array}$ \\
\hline 참고문헌 & $\begin{array}{l}\text { Council on Academic Accreditation } \\
\text { in Audiology and Speech-Language } \\
\text { Pathology, } 2020\end{array}$ & $\begin{array}{l}\text { European Federation of Audiology } \\
\text { Societies, 2001; Goulios \& Patuzzi, } \\
2008\end{array}$ & $\begin{array}{l}\text { Audiological Testing Service, } \\
2020\end{array}$ \\
\hline
\end{tabular}

Appendix 2. ISO 21388과 KSI 0562의 보청기 전문가 교육 기준

\begin{tabular}{|c|c|c|}
\hline 분류 & ISO 21388 & KS I 0562 \\
\hline \multirow[t]{2}{*}{ 이론 } & $\begin{array}{l}\text { 기초, 생의학, 인간·사회과학, 청각학, 보청기 기술, 청각재활, } \\
\text { 이어몰드, 맞춤형 귓본, 보청기 선택, 적합, 적합 확인 }\end{array}$ & 기초, 청각평가, 청각기기, 청능재활 \\
\hline & 1,420 시간 & 300시간 \\
\hline \multirow{2}{*}{ 실무/실습 } & 보청기적합, 수리, 연구과제 & 기초, 청각평가, 청각기기, 청능재활 \\
\hline & 830시간 & 240시간 \\
\hline \multirow[t]{2}{*}{ 추가 교육 } & 보충교과: 보청기전문가 관리 & 현장종합실습 \\
\hline & 340시간 & 960시간 \\
\hline 총 교육시간 & 2,590 시간 & 1,500 시간 \\
\hline 보수 교육 & 매년 최소 10시간(20시간 권고) & 매년 최소 16시간 \\
\hline 참고문헌 & International Organization for Standardization, 2020 & $\begin{array}{l}\text { Korean Agency for Technology and Standards, } \\
2018\end{array}$ \\
\hline
\end{tabular}

ISO: International Organization for Standardization, KS: Korean Industrial Standards 
Appendix 3. 국가직무능력표준(NCS) 청각관리의 능력단위 내용과 교육 수준

\begin{tabular}{|c|c|c|c|}
\hline 능력단위 & 능력단위요소 & 능력수준 & 학위 예시 \\
\hline 행동청능평가 & $\begin{array}{l}\text { 1) 순음청력 검사하기, 2) 어음청각검사하기, 3) 아동청각검사하기, 4) 기타 } \\
\text { 검사하기, 5) 행동청능평가 보고서 작성하기 }\end{array}$ & 5 & 석사 \\
\hline 전기생리청각평가 & $\begin{array}{l}\text { 1) 이미턴스검사하기, 2) 이음향방사검사하기, 3) 전기와우도검사하기, } \\
\text { 4) 청성뇌간반응검사하기, 5) 청성지속반응검사하기, 6) 청성중기 및 후 } \\
\text { 기 반응검사하기, 7) 전기생리청각평가 보고서 작성하기 }\end{array}$ & 4 & 학사 \\
\hline 보청기적합관리 & $\begin{array}{l}\text { 1) 보청기 성능분석하기, 2) 보청기 대상자 선정하기, 3) 귓본 채취하기, } \\
\text { 4) 보청기 선정하기, 5) 보청기 조절하기, 6) 보청기 물리적 변형하기, } \\
\text { 7) 보청기 착용효과 평가하기, 8) 보청기 사후관리하기, 9) 보청기적합관 } \\
\text { 리 보고서 작성하기 }\end{array}$ & 6 & 석사 \\
\hline 이식형청각기기기적합관리 & $\begin{array}{l}\text { 1) 인공와우 매핑하기, 2) 인공와우 착용효과 평가하기, 3) 기타이식형청각 } \\
\text { 기기 매핑하기, 4) 기타이식형청각기기 착용효과 평가하기, 5) 이식형청 } \\
\text { 각기기 사후관리하기, 6) 이식형청각기기적합관리 보고서 작성하기 }\end{array}$ & 6 & 석사 \\
\hline 청능훈련 & $\begin{array}{l}\text { 1) 청능훈련계획 수립하기, 2) 청능훈련 상담하기, 3) 듣기훈련하기, } \\
\text { 4) 의사소통전략 훈련하기, 5) 청능훈련 보고서 작성하기 }\end{array}$ & 6 & 석사 \\
\hline 중추청각기능재활 & $\begin{array}{l}\text { 1) 중추청각기능 평가하기, 2) 중추청각기능재활 계획 수립하기, 3) 중추청 } \\
\text { 각기능재활 실시하기, 4) 중추청각기능재활 보고서 작성하기 }\end{array}$ & 6 & 석사 \\
\hline 전정기능재활 & $\begin{array}{l}\text { 1) 전정기능평가하기, 2) 전정기능재활 계획 수립하기, 3) 전정기능재활 실 } \\
\text { 시하기, 4) 전정기능재활 보고서 작성하기 }\end{array}$ & 6 & 석사 \\
\hline 이명재활 & $\begin{array}{l}\text { 1) 이명평가하기, 2) 이명재활 계획 수립하기, 3) 이명재활 실시하기, } \\
\text { 4) 이명재활 보고서 작성하기 }\end{array}$ & 6 & 석사 \\
\hline 청력보존 & $\begin{array}{l}\text { 1) 소음 평가하기, 2) 청력보호기기 적합하기, 3) 청력정도관리 운영하기, } \\
\text { 4) 청력보존프로그램 운영하기, 5) 청력보존 보고서 작성하기 }\end{array}$ & 7 & 박사 \\
\hline 청각관리교육연구개발 & $\begin{array}{l}\text { 1) 청각관리 교육 실시하기, 2) 청능평가 도구 연구개발하기, 3) 청능재활 } \\
\text { 전략 연구 개발하기, 5) 청각기기 신기술 연구개발하기 }\end{array}$ & 8 & 박사 \\
\hline 청각기기생산 & $\begin{array}{l}\text { 1) 청각기기 생산하기, 2) 청각기기 품질검사하기, 3) 청각기기 수리하기, } \\
\text { 4) 청각기기 인허가업무하기 }\end{array}$ & 4 & 학사 \\
\hline 청각산업경영 & $\begin{array}{l}\text { 1) 창업하기, 2) 인력 관리하기, 3) 세무회계 관리하기, 4) 마케팅 전략 자문 } \\
\text { 하기 }\end{array}$ & 8 & 박사 \\
\hline 청각관리지원 & $\begin{array}{l}\text { 1) 청각장애인의 가족상담 지원하기, 2) 유관 사회복지단체 지원프로그램 } \\
\text { 운영하기, 3) 소음관련 법정분쟁 자문하기, 4) 청능재활 바우처 서비스하 } \\
\text { 기, 5) 청각장애 인식개선 교육 지원하기, 6) 청능치료 지원하기, 7) 통합 } \\
\text { 교육 지원하기, 8) 개별화 교육 프로그램 지원하기 }\end{array}$ & 7 & 박사 \\
\hline
\end{tabular}

NCS: National Competency Standard

Appendix 4. 발달재활서비스 제공 인력 자격인증을 위한 교육 기준

\begin{tabular}{ll}
\hline \multirow{2}{*}{ 과목 } & \multicolumn{1}{c}{ 발달재활서비스 관련 과목: 청능재활 } \\
\cline { 2 - 3 } & 세부 내용 \\
\hline 공통과목 & - 공통필수: 장애아동의 이해 \\
& - 공통선택: 아동발달, 장애아동 부모 교육 및 상담, 상담심리학, 심리학개론, 윤리와 철학(재활사 윤리), \\
& 재활행정과 정책, 장애아동 진단 및 평가, 안전관리와 응급처치, 장애인 복지론, 신경과학개론 \\
전공과목 & - 전공필수(반드시 이수): 아동청각학, 청능재활, 청능재활실습, 청성유발전위평가 \\
& - 전공선택: 행동청능평가, 행동청능평가실습, 청성유발전위평가실습, 보청기평가 및 적합, 보청기평가 및 \\
& 적합 실습, 인공와우평가 및 적합, 인공와우평가 및 적합 실습, 청각보조기기, 청각학개론, 청각해부생리학, \\
& 교육청각학, 심리음향학, 중추청각처리장애평가 및 재활, 의사소통장애개론, 수화
\end{tabular}

보건복지부 고시 2020-335호 발달재활서비스 제공 인력의 자격 및 인정절차 기준 
Appendix 5. 발달재활서비스 제공 인력 자격인증 대상자 요건

\begin{tabular}{ll}
\hline 구분 & \multicolumn{1}{c}{ 세부 내용 } \\
\hline 2018. 9. 12 기준 이전 & 1) 자격기본법에 따라 등록된 발달재활서비스 관련 민간자격 \\
자격인증 대상자 요건 & 2) 발달재활서비스 관련 학과를 전공하여 고등교육법에 따른 전문학사 이상의 학위를 취득한 사람으로서 \\
& 발달재활서비스 관련 분야 경력이 1,200시간 이상인 사람 \\
& 위 1) 2)의 경우 전환 교육 30시간 수료 또는 유사과목 심의와 함께 발달재활서비스 제공 인력 자격인증을 \\
& 신청한 뒤 심의를 거쳐 자격인증서를 발급받을 수 있다.
\end{tabular}

Appendix 6. 미국, 독일, 호주, 캐나다, 영국, 대한민국의 청능사자격제도

\begin{tabular}{|c|c|c|c|c|c|c|}
\hline & 미국 & 독일 & 호주 & 캐나다 & 영국 & 대한민국 \\
\hline 최소 교육 수준 & 대학원(4년) & 대학교(3 4년) & $\begin{array}{l}\text { 대학원(5년: } \\
\text { 학사 }+ \\
\text { 석사) }\end{array}$ & $\begin{array}{l}\text { 대학원(2 3년: } \\
\text { 석사) }\end{array}$ & $\begin{array}{l}\text { 대학원 및 } \\
\text { 대학교 } \\
\text { (2 3년: 학사 } \\
\text { 또는 석사) }\end{array}$ & $\begin{array}{l}\text { 대학원(2년) 또는 } \\
\text { 대학교(4년) }\end{array}$ \\
\hline 최소 임상수련 요건 & 12 개월 & 없음 & 12 개월 & 350시간 & 없음 & 없음 \\
\hline 개설 대학 수 & 90 & 4 & 6 & 5 & 12 & 9 \\
\hline $\begin{array}{l}\text { 자격(면허)관리 } \\
\text { 주체 }\end{array}$ & 주 법령 & $\begin{array}{l}\text { 독일연방 } \\
\text { 법률 }\end{array}$ & $\begin{array}{l}\text { 전문단체 } \\
\text { (Audiology } \\
\text { Australia) }\end{array}$ & $\begin{array}{l}\text { 전문단체 } \\
\text { (Speech- } \\
\text { Language \& } \\
\text { Audiology } \\
\text { Canada) }\end{array}$ & $\begin{array}{l}\text { 전문단체 } \\
\text { (British } \\
\text { society of } \\
\text { Audiology) }\end{array}$ & $\begin{array}{l}\text { 전문단체 } \\
\text { ((주청능사자격검정원) }\end{array}$ \\
\hline 참고문헌 & $\begin{array}{l}\text { Goulios \& Patuzzi, } \\
\text { 2008; Council } \\
\text { on Academic } \\
\text { Accreditation } \\
\text { in Audiology } \\
\text { and Speech- } \\
\text { Language } \\
\text { Pathology, } \\
\text { 2020; Model } \\
\text { Regulations for } \\
\text { State Licensure, } \\
\text { 2016 }\end{array}$ & $\begin{array}{l}\text { Goulios \& } \\
\text { Patuzzi, } \\
\text { 2008; } \\
\text { European } \\
\text { Commission, } \\
\text { 2021; Yong } \\
\text { et al., } 2019\end{array}$ & $\begin{array}{l}\text { Audiology } \\
\text { Australia, } \\
2018\end{array}$ & $\begin{array}{l}\text { Speech- } \\
\text { Language \& } \\
\text { Audiology } \\
\text { Canada, } \\
2021\end{array}$ & $\begin{array}{l}\text { Goulios \& } \\
\text { Patuzzi, } \\
\text { 2008; Yong } \\
\text { et al., } 2019\end{array}$ & $\begin{array}{l}\text { Audiological Testing } \\
\text { Service, } 2020\end{array}$ \\
\hline
\end{tabular}

